\title{
The seasonal trade-off between food and cover in the Alpine mountain hare (Lepus timidus)
}

\author{
Maik Rehnus $^{1,2}$ • Veronika Braunisch ${ }^{3,4}$ - Klaus Hackländer ${ }^{2,5}$ • Lea Jost ${ }^{6}$. \\ Kurt Bollmann ${ }^{1}$
}

Received: 3 October 2014 / Revised: 3 September 2015 / Accepted: 7 September 2015 /Published online: 14 September 2015

(C) Springer-Verlag Berlin Heidelberg 2015

\begin{abstract}
Habitat use of prey species is often subjected to strong trade-offs when foraging needs and predator avoidance cannot be met simultaneously. Trade-offs may be particularly pronounced for species dwelling above ground throughout the year. Identifying habitat use of such species may help to determine crucial and limited environmental resources and has strong implications for habitat management. We investigated the relative importance of habitat structure and composition for mountain hares in the Swiss Alps at the small scale for two time periods, throughout the year and during the reproductive period. Habitat use was assessed by a non-invasive approach that considers the spatio-temporal distribution of fecal pellets, sampled along systematically distributed transects. We found that heterogeneous habitats with high diversity of vegetation layers and/or abundance of saplings and storeyed vegetation structures are strongly used. The availability of shelter was more important in summer when hares strongly used dense
\end{abstract}

Maik Rehnus

maik.rehnus@gmx.de

1 Swiss Federal Institute for Forest, Snow and Landscape Research WSL, Zürcherstrasse 111, 8903 Birmensdorf, Switzerland

2 Institute of Wildlife Biology and Game Management, University of Natural Resources and Life Sciences, Vienna, Gregor-Mendel-Str. 33, 1180 Vienna, Austria

3 Forest Research Institute of Baden-Württemberg, Wonnhaldestrasse 4, 79100 Freiburg, Germany

4 Conservation Biology, Institute of Ecology and Evolution, University of Bern, Baltzerstrasse 6, 3012 Bern, Switzerland

5 Present address: Program in Fisheries, Wildlife and Conservation Biology, North Carolina State University, Raleigh, NC, USA

6 Department of Environmental Sciences, ETH Zurich, ETH Zentrum, CHN H41, 8092 Zurich, Switzerland habitats that offered protection from predators. The availability of food was more important as predictor for year-round use compared to the reproductive period when food is overabundant for hares. A heterogeneous habitat provides an optimal distribution and availability of shelter and food resources and allows the hare to adjust its activity pattern to changing environmental conditions. Therefore, the occurrence of a structurally heterogeneous ecotone at the upper timber line with a mosaic of different vegetation types and hiding structures should be considered in the management of the species.

Keywords Food $\cdot$ Habitat use $\cdot$ Patchiness $\cdot$ Pellets $\cdot$ Shelter . Structure $\cdot$ Transect

\section{Introduction}

The spatio-temporal pattern of a species habitat use is a crucial key for the understanding of its distribution and abundance (Krebs et al. 2001). Insights into habitat use contribute to the effective conservation and management of investigated species (Boyce and McDonald 1999; Nielsen et al. 2006). Yet, patterns of habitat use are rarely consistent over time due to pronounced seasonal changes in habitat requirements and quality, such as the availability of food and shelter (Marchand 1991). Moreover, habitat use is often subjected to a strong trade-off when different needs in foraging and predator avoidance cannot be met at the same place. This trade-off may be particularly pronounced in prey species living under harsh environmental conditions that offer only limited possibilities for optimizing all requirements simultaneously. Identifying the habitat use of such species may have strong implications for its management.

The mountain hare (Lepus timidus) has an arctic-alpine distribution, with palearctic occurrences in tundra and taiga 
habitats from Ireland to Japan, as well as isolated populations in the European Alps (Thulin and Flux 2003). The species is a potential prey of several endangered species in the Alps (e.g., golden eagle Aquila chrysaetos, eagle owl Bubo bubo, and lynx Lynx lynx) and a traditional game species in several regions (Rehnus 2013). The mountain hare is active throughout the year and well adapted to seasonal environmental changes, with flexible seasonal and 24-h activity cycles that allow for adapting its food and cover needs to local conditions (Hewson 1990; Rehnus 2014). The species can reduce its metabolic rate in winter (Nieminen and Mustonen 2008; Pyörnila et al. 1992; Rehnus et al. 2010; Thulin and Flux 2003), as well as adjust its daily activity budget to cope with alpine conditions (Nodari 2006; Rehnus et al. 2013; Slotta-Bachmayr 1998) by an opportunistic feeding strategy (Hulbert et al. 2001; Iason and Van Wieren 1999; Loidl 1997; Rehnus et al. 2013).

The availability of food and shelter are the two most important factors affecting a hare's habitat use (Bisi et al. 2013; Hewson and Hinge 1990; Hiltunen et al. 2004; Hulbert et al. 1996; Keith and Windberg 1978; Nodari 2006; Pehrson and Lindlöf 1984; Wolff 1980). Previous studies have shown that the availability of shelter against predators is more important than the availability of food because hares prefer habitat types that offer security from predators over habitat types that offer high-quality food (Hik 1995; Wolff 1980). Yet, this use pattern can be expected to vary seasonally, as the relative costs (lower food quality) and benefits (lower risk of predation) associated with occupying each habitat may vary with environmental conditions and changing requirements throughout the individual's reproductive cycle (Lima and Dill 1990). For instance, open habitats with high-quality food generally allow hares to forage efficiently (high nutrient intake in a short time) and to readily sense and escape from terrestrial predators. However, such open habitats increase the risk of being detected (Mills et al. 2004). The tendency to minimize predation risk may be particularly pronounced during certain periods of an individual life, such as the lactation period (Olsson et al. 2008). Seasonal differences in the importance of habitats rich in undergrowth can also be expected because they limit the loss of body heat by buffering the exposure to wind (Grace and Easterbee 1979), thereby reducing the hare's energy demands. However, knowledge about the relative importance of various habitat elements and the factors influencing habitat use is sparse, in particular for mountain hares.

In this study, we addressed how habitat and vegetation structures at the small scale are related to seasonal habitat use of the mountain hare. We expect a seasonal change in habitat use due to changes in shelter and food availability, and that hare occurrence increases with the abundance of hiding elements. Further, we provide evidence-based recommendations for habitat management.

\section{Materials and methods}

\section{Study area}

The study was conducted in the Swiss Alps, in six study sites (Fig. 1, A to F with total $44.0 \mathrm{~km}^{2}$ ) located in three biogeographic regions (two sites per region) (Gonseth et al. 2001). The sites were selected so as to represent the overall area occupied by the mountain hare with different climatic conditions and composition of tree species, yet excluding areas of sympatric occurrence with the European hare (Lepus europaeus). Mountain hares in the Alps occur between 700 and $3800 \mathrm{~m}$ a.s.l., and the distribution may overlap with European hares at the lower altitudes (Rehnus 2013) which were excluded our study. Evidence for allopatric occurrence in the study sites A, B, E, and F stem from interviews with local hunters and representatives of the cantonal wildlife departments; allopatry in sites $\mathrm{C}$ and $\mathrm{D}$ was confirmed by longterm observations of park rangers in the Swiss National Park between 1979 and 2012 (Swiss National Park unpublished) and interviews of local hunters and gamekeepers from nearby hunting districts (Rehnus unpublished).

\section{The Northern Alps (study sites A and B)}

The Northern Alps are characterized by an oceanic climate with dominant winds from the north and the west. Precipitation exceeds $1200 \mathrm{~mm} /$ year at $1000 \mathrm{~m}$ a.s.l. (Ott et al. 1997), and temperatures are relatively cool compared to other regions and show slight daily and seasonal variations. The soil substratum is primarily limestone, but silicates also occur. Spruce (Picea abies) dominates the forests in the subalpine zone and co-occurs with fir (Abies alba) at lower elevations. The timber line in study site A and B was between 1800 and $1900 \mathrm{~m}$ a.s.l. and 1900-2000 $\mathrm{m}$ a.s.l., respectively.

\section{The Central Alps (C, D)}

In the Central Alps, a continental climate prevails. The valleys are largely protected from oceanic and insubric (mild and wet) influences by the Alpine massif. Precipitation is low, with an average of 600-900 mm/year at $1000 \mathrm{~m}$ a.s.l. (Ott et al. 1997). Temperatures show high daily and seasonal variations, and solar radiation in this region is high (Ott et al. 1997). The substratum consists of limestone and silicates. Subalpine forests are dominated by spruce with larch (Larix decidua) and Swiss stone pine (Pinus cembra) taking over at higher elevations. In addition, Swiss stone pine occurs with mountain pine 
Fig. 1 The distribution of mountain hares in Europe, according to Thulin (2003), and locations of the six study sites $(A$ $46^{\circ} 35^{\prime} \mathrm{N}, 7^{\circ} 43^{\prime} \mathrm{E} ; B 46^{\circ} 40^{\prime} \mathrm{N}, 8^{\circ} 7^{\prime}$ $\mathrm{E} ; C 46^{\circ} 39^{\prime} \mathrm{N}, 10^{\circ} 11^{\prime} \mathrm{E} ; D 46^{\circ} 42^{\prime}$ $\mathrm{N}, 10^{\circ} 16^{\prime} \mathrm{E} ; E 46^{\circ} 17^{\prime} \mathrm{N}, 8^{\circ} 28^{\prime} \mathrm{E} ; F$ $\left.46^{\circ} 10^{\prime} \mathrm{N}, 9^{\circ} 8^{\prime} \mathrm{E}\right)$ in the biogeographical regions Northern Alps (black), Central Alps (light gray), and Southern Alps (dark gray) in Switzerland (Gonseth et al. 2001; adapted)

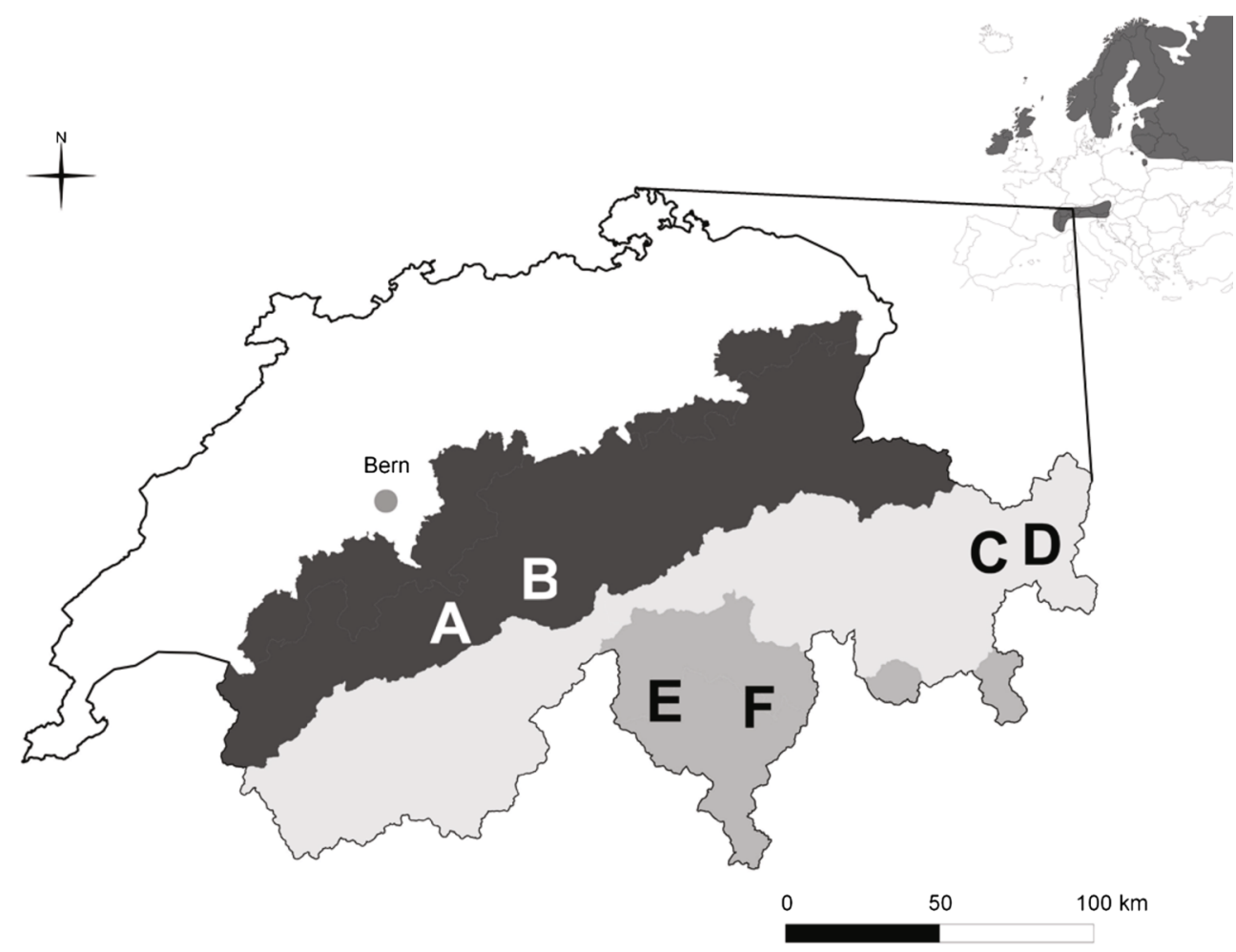

(Pinus mugo) along the upper timber line and/or in areas influenced by avalanches. Scotch pine (Pinus silvestris) occurs at lower elevations (Ott et al. 1997). The timber line in study site $\mathrm{C}$ was between 2200 and $2300 \mathrm{~m}$ a.s.l. and in study sites $\mathrm{D}$ between 2100 and $2200 \mathrm{~m}$ a.s.l.

\section{The Southern Alps (E, F)}

Mountain ranges of the Southern Alps are influenced by a mild climate with winds from the south and the west and heavy precipitation events during a year. The average annual precipitation at $1000 \mathrm{~m}$ a.s.l. is $>2000 \mathrm{~mm} /$ year; temperatures are warm and solar radiation is high (Ott et al. 1997). The substratum is mostly silicate. In the subalpine zone, larch and Swiss stone pine are the predominant tree species next to spruce and fir at lower elevations. The timber line in study site $\mathrm{E}$ and $\mathrm{F}$ was between 2000 and $2100 \mathrm{~m}$ a.s.l. and 1900$2000 \mathrm{~m}$ a.s.l., respectively.

\section{Transect description}

We assessed the habitat use of mountain hare by surveying for the presence of fecal pellets on transects. Pellet surveys are a cost- and time-effective method (Krebs et al. 2001; Litvaitis et al. 1985) for indexing habitat use by hares (Lepus americanus, Adams 1959; Erwacha et al. 2014; Hodges et al. 2009; Lewis et al. 2011; Litvaitis et al. 1985; Newbury and Simon 2005; O’Donoghue 1983; Wolff 1980; L. europaeus, Perry and Robertson 2012; L. timidus,
Angerbjörn 1983; Hiltunen and Kauhala 2006), and transects have proven to be useful for assessing the spatio-temporal distribution of lagomorph species (Angerbjörn 1983; Hiltunen and Kauhala 2006; Murray et al. 2005). Knowledge of mountain hare densities were limited or unknown in most study sites. To be effective in finding pellets and assessing a representative distribution pattern, we surveyed 2-m-wide line transects along all contour lines at $100-\mathrm{m}$ intervals. Steep rocky sites and inaccessible parts on transects (e.g., rock falls), for instance, were excluded because they were considered unsuitable for hares (Nodari 2006). A total length of $67.9 \mathrm{~km}$ transects were surveyed. Transect length differed between study sites (Table 1). The length of individual transects ranged between 0.2 and $1.9 \mathrm{~km}$ between all sites.

\section{Species data}

Surveys were carried out in early summer and autumn of the year 2012. In order to balance the variation in the detection probability of pellets, surveys in the six study sites were undertaken in periods of congruent vegetation stage. Surveys were conducted by two observers. To ensure a high pellet detection accuracy which can vary between experienced and unexperienced persons up to $8 \%$ (Rehnus unpublished), the unexperienced field worker was trained before fieldwork.

During the first survey, all occurrences of mountain hare pellets were mapped and afterwards cleared from transects. The first survey was conducted shortly after snow-melt, between mid-June and the beginning of 
Table 1 Elevation range and length of surveyed transects (I) and number of pellet locations in two time periods (summer and year-round (II)) in the six study sites (A to F) in the Northern, Central, and Southern Alps of Switzerland

\begin{tabular}{|c|c|c|c|c|c|c|c|}
\hline & & \multicolumn{2}{|l|}{ North } & \multicolumn{2}{|l|}{ Central } & \multicolumn{2}{|l|}{ South } \\
\hline & & A & $\mathrm{B}$ & $\mathrm{C}$ & $\mathrm{D}$ & $\mathrm{E}$ & $\mathrm{F}$ \\
\hline \multirow[t]{14}{*}{ (I) } & Elevation range (m a.s.1.) & $1600-2200$ & $1600-2500$ & $1700-2500$ & $1700-2400$ & $1600-2400$ & $1600-2200$ \\
\hline & Total length of transects $(\mathrm{km})$ & 11.7 & 13.1 & 18.1 & 6.5 & 9.7 & 8.8 \\
\hline & Transect length at 1600 a.s.1. $(\mathrm{km})$ & 0.9 & 2.8 & - & - & 1.2 & 1.0 \\
\hline & Transect length at 1700 a.s.1. $(\mathrm{km})$ & 3.0 & 2.1 & 1.7 & 0.9 & 2.3 & 1.4 \\
\hline & Transect length at 1800 a.s.l. $(\mathrm{km})$ & 1.9 & 0.9 & 2.7 & 0.7 & 1.8 & 1.7 \\
\hline & Transect length at 1900 a.s.l. $(\mathrm{km})$ & 1.4 & 1.0 & 2.5 & 1.0 & 1.0 & 1.9 \\
\hline & Transect length at 2000 a.s.1. $(\mathrm{km})$ & 1.9 & 2.6 & 2.3 & 0.6 & 0.9 & 1.7 \\
\hline & Transect length at 2100 a.s.1. $(\mathrm{km})$ & 2.0 & 1.0 & 1.6 & 0.8 & 0.7 & 0.8 \\
\hline & Transect length at 2200 a.s.1. (km) & 0.6 & 1.2 & 1.2 & 0.6 & 1.0 & 0.2 \\
\hline & Transect length at 2300 a.s.1. $(\mathrm{km})$ & - & 0.2 & 1.5 & 1.0 & 0.3 & - \\
\hline & Transect length at 2400 a.s.1. $(\mathrm{km})$ & - & 0.7 & 1.8 & 0.9 & 0.4 & - \\
\hline & Transect length at 2500 a.s.1. $(\mathrm{km})$ & - & 0.8 & 2.7 & - & - & - \\
\hline & Area of study site $\left(\mathrm{km}^{2}\right)$ & 9.7 & 11.4 & 9.6 & 6.7 & 4.3 & 2.3 \\
\hline & Transect length per unit area $\left(\mathrm{km} / \mathrm{km}^{2}\right)$ & 1.2 & 1.1 & 1.9 & 1.0 & 2.3 & 3.8 \\
\hline \multirow[t]{2}{*}{ (II) } & Total number of plots year-round $(N)$ & 45 & 110 & 272 & 148 & 115 & 104 \\
\hline & Total number of plots summer $(N)$ & 47 & 141 & 289 & 153 & 126 & 101 \\
\hline
\end{tabular}

July, and before green-up when emerging herbaceous plants cover the ground. Thus, we ensured high detection of pellets because pellet detection can be influenced by the type and density of understory vegetation (Neff 1968). The GPS position of each pellet location (defined as a minimum of one pellet with a minimum distance of $20 \mathrm{~m}$ to the next observation) was recorded (Garmin GPSmap $60 \mathrm{CSx}$ ). The pellets surveyed during this first inventory were assumed to represent habitat use during all seasons before cleaning (further called "year-round"). Counts of pellets on uncleared plots are considered to be adequate for ranking relative hare abundance (Mills et al. 2005; Murray et al. 2002) and are well established to study relative abundances of snowshoe hares (Erwacha et al. 2014; Hodges et al. 2009; Lewis et al. 2011; Newbury and Simon 2005).

Between mid-September and mid-October, after an average of 85 days, transects were revisited. The pellets mapped during the second survey therefore represent habitat use in summer only. To estimate the influence of the ground vegetation cover on the detection probability of pellets in the vegetation period, we estimated the detection rate for the four major vegetation types in a field experiment (Rehnus unpublished). The rates were high for single pellet ( 0.97 on scree, 0.97 on litter, 0.90 on Ericaceae, 0.88 on grass), and for pellet groups with three pellets (1.00 on all types of ground cover; Rehnus unpublished). These figures indicate high detection probabilities for pellet locations during the second survey.

\section{Habitat variables}

To compare habitat characteristics of plots with and without evidence of mountain hare use, we randomly selected - for both time periods (year-round and summer) - an equivalent number of random plots among transects. All random plots did not contain pellets at the first survey. However, pellets were found in 73 of these random plots at the second survey. These plots were classified as presence for summer but were not included in the absence dataset for year-round, as ascertained summer presence also entailed year-round presence. In summary, plot number for year-round was 794 and for summer 857 (Table 1).

Habitat characteristics were recorded at each pellet and random location within a circular plot with a radius of $3 \mathrm{~m}$. We assumed that a plot size of $28 \mathrm{~m}^{2}$ characterizes the smallscale habitat use of mountain hares. We recorded habitat variables that characterize shelter and food availability as well as comfort resources (Table 2). Resource variables were defined according to existing literature for mountain hares (Rehnus 2013; Sokolov et al. 2009; Thulin and Flux 2003).

\section{Data analysis}

\section{Habitat use}

Mountain hare occurrence was modeled as a function of habitat composition using Mixed Effects Logistic Regression 
Table 2 Habitat variables used for analyzing mountain hare habitats at sampling plots distributed across six study sites in the Northern, Central, and Southern Alps of Switzerland

\begin{tabular}{|c|c|c|}
\hline Habitat variable & Resource & Description \\
\hline Vegetation successional stage & Food and shelter & $\begin{array}{l}\text { Successional stage in six classes (Keller 2005): non-forested, } \\
\text { sapling (diameter at breast height } \mathrm{DBH}<10 \mathrm{~cm}) \text {, pole } \\
(10 \mathrm{~cm}<\mathrm{DBH}<30 \mathrm{~cm}) \text {, timber }(30 \mathrm{~cm}<\mathrm{DBH}<60 \mathrm{~cm}), \\
\text { mature (DBH }>60 \mathrm{~cm}) \text {, storeyed (mix of trees with different } \\
\text { DBH-classes) }\end{array}$ \\
\hline Horizontal dead wood & Shelter & $\begin{array}{l}\text { Presence/absence of fallen dead trees (diameter } \geq 12 \mathrm{~cm} \text { and } \\
\text { length } \geq 1.3 \mathrm{~m} \text { ) }\end{array}$ \\
\hline Basal-branched trees & Shelter & $\begin{array}{l}\text { Presence/absence of trees or groups of trees } \geq 5 \mathrm{~m} \text { in height; } \\
\text { basal branches must be } \leq 0.5 \mathrm{~m} \text { above the ground }\end{array}$ \\
\hline Grass-sedge cover & Food & $\begin{array}{l}\text { Proportion of grasses and sedges at the investigated plot in } \\
10 \% \text { - classes }\end{array}$ \\
\hline Dwarf-shrub cover & Food and shelter & $\begin{array}{l}\text { Proportion of dwarf trees and shrubs }(1.3 \mathrm{~m} \geq \text { height }<5 \mathrm{~m}) \\
\text { at the investigated } \\
\text { plot in } 10 \% \text { - classes }\end{array}$ \\
\hline Other vegetation cover & Food & $\begin{array}{l}\text { Proportion of other ground vegetation (e.g., Bryophytes) } \\
\text { at the investigated plot in } 10 \% \text {-classes }\end{array}$ \\
\hline Layer diversity & Food and shelter & $\begin{array}{l}\text { Shannon diversity index of cover layer (scree, grass-sedges, } \\
\text { dwarf-shrub, other vegetation, bare ground, and tree cover), } \\
\text { calculated by Shannon and Weaver (1963), where an index } \\
\text { value of } 0 \text { means no diversity in cover layers }\end{array}$ \\
\hline Tree cover & Shelter & $\begin{array}{l}\text { Proportion of trees (height } \geq 5 \mathrm{~m} \text { ) at the investigated plot in } \\
10 \% \text { - classes }\end{array}$ \\
\hline Scree cover & Shelter & $\begin{array}{l}\text { Proportion of scree at the investigated plot (height } \geq 10 \mathrm{~cm} \text { ) } \\
\text { in } 10 \% \text { - classes }\end{array}$ \\
\hline Bare ground cover & Comfort & $\begin{array}{l}\text { Proportion of bare (e.g., for sand bath) ground at the } \\
\text { investigated plot in } 10 \% \text { - classes }\end{array}$ \\
\hline Vegetation height & Food and shelter & $\begin{array}{l}\text { Average height of grass-sedge cover, dwarf-shrubs, and other } \\
\text { vegetation in } 5 \mathrm{~cm} \text { - classes }\end{array}$ \\
\hline Tree height & Shelter & Average tree height (height $\geq 5 \mathrm{~m}$ ) in $1 \mathrm{~m}$-classes \\
\hline
\end{tabular}

with the study site and biogeographic region as random effect to account for spatial clustering and to consider the area occupied by the mountain hare with different climatic conditions and composition of tree species. We selected only variables with a pairwise Pearson correlation of $r<0.5$ for our models. We applied a model selection approach (Burnham and Anderson 2002), based on Akaike Information Criteria (AICc $=$ AIC with a correction for small sample sizes) (Johnson and Omland 2004), to identify the most parsimonious model from a set of candidate models generated from all possible variable combinations using the R-package MuMIN (Barton 2014). Akaike weights $\left(\mathrm{AIC}_{\mathrm{w}}\right)$ were calculated to indicate the level of support for a given model relative to all models in the candidate model set (Burnham and Anderson 2002). To estimate relative importance of selected variables, we calculated their $\Delta \mathrm{AIC}_{\mathrm{c}}$ to the calculated $\mathrm{AIC}_{\mathrm{c}}$ of the best model for year-round and summer habitat use.

To quantify the models' accuracy to predict yearround and summer habitat use, we used spatial crossvalidation calculating the mean and standard error of squared-error losses. The squared-error loss averages the squares of the "errors," i.e., the amount by which the value implied by the estimator differs from the quantity estimated. A squared-error loss of zero means that the estimator predicts observations of the parameter with perfect accuracy. All analyses were performed in R 3.0.2. (R Development Core Team 2013).

\section{Results}

\section{Species data}

Observed densities of pellet locations were higher during the first survey (representing year-round habitat use) compared to the second (summer). The highest densities of pellet locations were found in the two sites $\mathrm{C}$ and $\mathrm{D}$ in both seasons (Fig. 2).

In most study sites, pellet densities followed the same altitudinal pattern: the highest densities were found in the timberline zone. Above the timberline, in the adjacent areas dominated by alpine pastures, pellet densities declined, but 


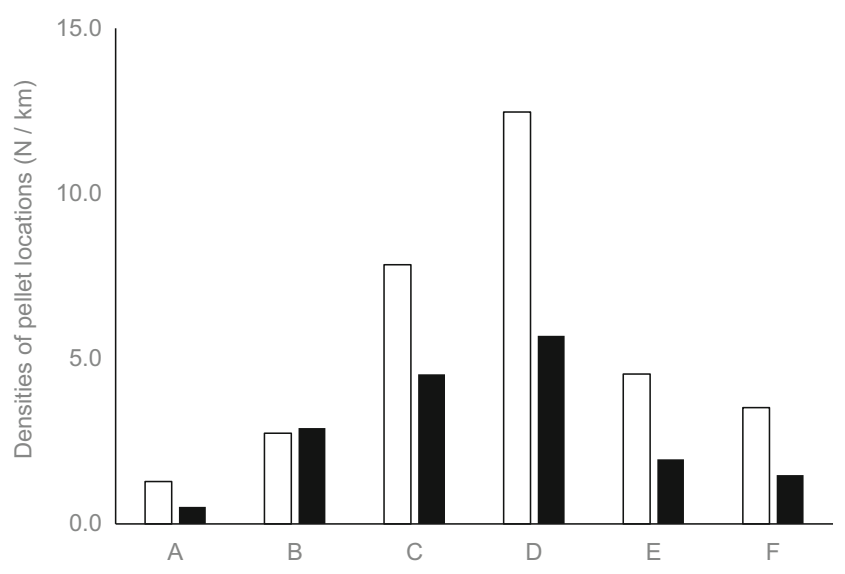

Fig. 2 Densities of pellet locations $(N / \mathrm{km})$ of mountain hares year-round (white) and during summer (black) in the six study sites in the Northern $(A, B)$, Central $(C, D)$, and Southern Alps $(E, F)$ of Switzerland

increased again in the highest areas which are dominated by scree (Appendix).

\section{Habitat use}

The best model selected to explain year-round habitat use contained more than twice the number of habitat variables as compared to the best summer model (Table 3 ). Layer diversity and vegetation successional stage were important predictors of the year-round and summer models, whereas the cover of grass-sedge, dwarf-shrub, basal-branched trees, and other vegetation were only important in the year-round model. The presence of mature stands (year-round) and timber stands (summer) had a negative effect on the occurrence of the mountain hare while the other variables had positive effects (Table 3). In both the year-round and summer models, layer diversity showed the highest relative importance of the selected predictor variables (Table 3 ).

\section{Discussion}

Our study shows that the trade-off of mountain hares between foraging needs and predator avoidance can be best achieved in heterogeneous habitats that provide a suitable distribution of shelter and food under changing seasonal conditions.

\section{Species data}

The higher densities of pellet locations recorded during the first survey in early summer on uncleared plots were expected because pellets accumulate over an unknown period (Murray et al. 2005; Prugh and Krebs 2004).

The observed densities varied between study sites during both surveys, suggesting differences in population densities (Krebs et al. 1987; Mills et al. 2005; Murray et al. 2002).
Due to the high persistence of pellets, we assume that only a minimal number of pellets have disappeared during the survey periods. Thus, possible differences in decay rates among the six study sites, e.g., due to different climatic conditions, are negligible. It is not known how small-scale differences in habitat type influence pellet-decay rates of hares (e.g., Prugh and Krebs 2004; Perry and Robertson 2012). Prugh and Krebs (2004) showed that habitat-specific decay rates can occur over years-likely due to differences in microsite moisture levels and substrate type - but only $1 \%$ of pellets of snowshoe hare had disappeared in the willow (Salix ssp.) habitat after 1 year. Median persistence time of pellets was approximately 6 years. In our study, a potential degradation of hare pellets by leaf litters (Eaton 1993) can be excluded because investigated sites were dominated by conifers. According to Perry and Robertson (2012), pellet counts on uncleared plots are not unduly biased by differential decay rates. In analogy, we assume that pellet counting works particularly well in alpine climates with snowy winters and cold summer climate which both are expected to delay the breakdown of pellets by insects and bacteria.

The highest densities of pellets were observed in the two sites located in the Central Alps in the Swiss National Park (sites C and D; Fig. 1). It is a Strict Nature Reserve of category Ia according to the IUCN classification (IUCN 2014) that was established 100 years ago. There, forest use, agricultural activities, and hunting are prohibited and touristic activities are restricted to designated trails during the snow-free period and the closure of the park area during the winter seasons with snow cover (Haller et al. 2013). Natural reforestation on previous Alpine farmland which was used as summer pastures is strongly delayed because these subalpine grasslands are heavily grazed by red deer Cervus elaphus and chamois Rupicapra rupicapra (Schütz et al. 2003). Thus, an upper forest ecotone with habitats composed of heterogeneous structures has been preserved in the Park. This suitable habitat in combination with spatially and temporally predictable human activities and a relatively low amount of precipitation might explain the high densities of pellets. High precipitation during the reproduction period or in winter cause higher mortality of hares (Kielland et al. 2010), whereas restricted touristic activities allow mountain hares to cope with human disturbance (Rehnus et al. 2014).

As expected, we found the highest densities of pellets around the timberline in most study sites. This region is known to represent the core distribution of mountain hares in the European Alps (Rehnus 2013; Slotta-Bachmayr 1998). We assume that mountain hare feed on alpine pastures and move to sites with shelter at higher or lower altitudes of their home ranges. There, they can safely re-ingest their pellets in scree or sapling stands (Hirakawa 2001). 
Table 3 Models explaining habitat use of mountain hares year-round and during summer (I), with model parameter estimates incl. standard errors and $p$ values $(* * *<0.001, * *<0.01$,

$*<0.05$ ) (II), and relative importance of selected variables by increasing $\triangle \mathrm{AIC}_{\mathrm{c}}$ values compared to the full model (III)

\begin{tabular}{|c|c|c|c|c|c|c|}
\hline \multirow[t]{3}{*}{ (I) } & Season & Model & Intercept & $K$ & $\log L$ & $\mathrm{AIC}_{\mathrm{w}}$ \\
\hline & Year-round & $\begin{array}{l}\text { Basal-branched trees }+ \text { dwarf-shrub } \\
\text { cover }+ \text { vegetation successional } \\
\text { stage }+ \text { grass-sedge cover }+ \text { other } \\
\text { vegetation cover }+ \text { layer diversity }\end{array}$ & -2.23 & 12 & -527.18 & 0.79 \\
\hline & Summer & $\begin{array}{l}\text { Vegetation successional stage }+ \\
\text { layer diversity }\end{array}$ & -2.19 & 8 & -436.43 & 1.00 \\
\hline \multirow[t]{17}{*}{ (II) } & Season & Variable & Estimate & SE & $p$ value & \\
\hline & Year-round & Sapling stands & 0.98 & 0.31 & $0.001^{* *}$ & \\
\hline & & Pole stands & 0.57 & 0.64 & 0.373 & \\
\hline & & Timber stands & 0.17 & 0.22 & 0.439 & \\
\hline & & Mature stands & -0.52 & 0.38 & 0.170 & \\
\hline & & Storeyed stands & 0.53 & 0.28 & 0.057 & \\
\hline & & Layer diversity & 0.93 & 0.23 & $<0.001 * * *$ & \\
\hline & & Basal-branched trees & 0.69 & 0.26 & $0.008 * *$ & \\
\hline & & Grass-sedges cover & 0.01 & 0.00 & $<0.001 * * *$ & \\
\hline & & Dwarf-shrub cover & 0.01 & 0.00 & $<0.001 * * *$ & \\
\hline & & Other vegetation cover & 0.02 & 0.01 & $0.015^{*}$ & \\
\hline & Summer & Sapling stands & 0.67 & 0.28 & $0.018^{*}$ & \\
\hline & & Pole stands & 0.14 & 0.70 & 0.836 & \\
\hline & & Timber stands & -0.76 & 0.25 & $0.003 * *$ & \\
\hline & & Mature stands & 0.16 & 0.43 & 0.704 & \\
\hline & & Storeyed stands & 0.27 & 0.28 & 0.349 & \\
\hline & & Layer diversity & 1.13 & 0.25 & $<0.001 * * *$ & \\
\hline \multirow[t]{9}{*}{ (III) } & Season & Variable & $\Delta \mathrm{AICc}$ & & & \\
\hline & Year-round & Layer diversity & 14.0 & & & \\
\hline & & Dwarf-shrub cover & 13.0 & & & \\
\hline & & Grass-sedges cover & 10.4 & & & \\
\hline & & Vegetation successional stage & 6.4 & & & \\
\hline & & Basal-branched trees & 5.1 & & & \\
\hline & & Other vegetation cover & 4.0 & & & \\
\hline & Summer & Layer diversity & 19.0 & & & \\
\hline & & Vegetation successional stage & 12.9 & & & \\
\hline
\end{tabular}

With an average squared-error loss of $0.17(\mathrm{SE} \pm 0.01$; range $0.14-0.20)$, habitat use in summer was more accurately predicted than year-round $(0.24 \pm 0.02$; range $0.15-0.28)$

$K$ number of parameters, $\log L$ maximized log-likelihood, $A I C_{w}$ AICc weight

\section{Habitat use}

The positive influence of layer diversity on year-round and summer habitat use mirrors the mountain hares' preference for heterogeneous habitat structures (Sokolov et al. 2009) and terrain roughness. Highly diverse and patchy habitats better meet the food and shelter needs of mountain hares living in seasonally variable environments. For instance, some deciduous shrub species like green alder (Alnus sp.) lose their leaves in fall and, thus, increase a hare's predation risk. Snow cover may impede the access to some shelters and food resources, but it may also influence the availability of new shelters and food resources when heavy snow causes branches to bend toward the ground. Occurrence of snow increases the detectability of mountain hares, for example, by fresh tracks but decrease the encounter rate by terrestrial predators such as the red fox Vulpes vulpes which cannot chase a hare with the same speed on soft snow. Snow depths at a given site is strongly modulated by its structural diversity (Gorini et al. 2012). Hence, habitat heterogeneity affects both the mobility of hares, who prefer hard snow (Rehnus 2013; SlottaBachmayr 1998), as well as the hunting efficiency of the red fox (Oksanen et al. 2001) and, thus, determines sites where mountain hares cope with their trade-off in needs for foraging and predator avoidance.

Habitats which are characterized by a high availability of hiding elements, e.g., sapling and storeyed vegetation successional stages, were used both throughout the year and in summer, while pellet density in other successional stages was low. In our study area, the former stages consist mainly of conifer 
species like spruce or Mountain pine which provide a constant availability of hiding elements throughout the year. Both woody species are important food resources for mountain hares (Loidl 1997; Rehnus et al. 2013). We conclude that vegetation successional stages which provide yearlong hiding elements and food resource seem to be most appropriate for mountain hares. Although conifer species are generally poor in nutrients and contain a lot of barely digestible cellulose and hemicellulose, they can be used by coprophagous species (Hirakawa 2001). During field work, we observed that mountain hares hide, for example, in Mountain pine sapling stands when they detect a predator and stay in this position as long as the predator is in safe distance, but escape from it when the predator gets closer. Mountain hare habitats that incorporate plenty of hiding structures lower the predation risk and provide shelter from which predators can be detected. This is in line with results from Focardi and Rizzotto (1999) who showed that habitat cover influence survival probability and body condition of hares and that their body constitution were worse in very open habitats.

Interestingly, our results emphasize the significance of forest vegetation close to and below the tree line ecotone compared to open areas above it, although hares can be observed far above the tree line up to $3800 \mathrm{~m}$ a.s.l. (Rehnus 2013). This is in line with results from Erwacha et al. (2014) which showed that snowshoe hares are more active in areas with greater forest cover, and with results from Rehnus (2013) and Slotta-Bachmayr (1998) which could confirm that the main distribution of mountain hares is around the timber line which also provides good protection from avian predators.

The fact that basal-branched trees were important for explaining year-round but not summer habitat use indicates their importance as shelter element during times of harsh weather conditions and during the snow season when alternative shelters are covered and inaccessible.

Grass-sedges, dwarf-shrub, and other vegetation cover were important for explaining year-round habitat use only, which indicates their importance as food resources throughout the year. This is in line with previous results which showed that graminoids, forbs, and dwarf shrubs are important food resources in spring and autumn accounting for about half of the total food intake at these seasons (Rehnus et al. 2013). Even in winter, these vegetation elements represent a quarter of mountain hares' diet (Rehnus et al. 2013) which is taken at sites free of snow due to wind or active clearing by hares (Rehnus 2013). Although females have been shown to prefer Gramineae during the peak breeding season (Hulbert et al. 2001), we could not confirm this finding in our study. We are convinced that hares in our study area also forage on abundant Gramineae and forbs of meadows and pastures. However, pellet counting seems not to adequately reflect this habitat use because the hares probably regularly return to sheltered sites within the forest. This would indicate the behavioral trade-off of wild animals to feed efficiently while avoiding predators (Lima and Dill 1990; Sih 1980). Open habitats usually imply higher visibility and higher encounter rates, but they also support prey species in their perception of danger (Mills et al. 2004). However, the flexible, opportunistic foraging habits of the mountain hare (Hulbert et al. 2001; Iason and Van Wieren 1999; Loidl 1997; Rehnus et al. 2013) support its demand for predator avoidance (Hik 1995; Rehnus et al. 2013) and lower the species' exposure to humans (Rehnus et al. 2014).

The model accuracy tended to be higher for the summer models compared to year-round predictions. This might be caused by the accumulation of pellets during the first survey that includes pellets from an unknown period, with seasonal differences in habitat selection patterns blurring the results. Squared-error losses in summer varied between sites and were higher at sites with high densities of pellets (B, C, and D). This may reflect a density-dependent habitat use because higher densities can force some individuals to use suboptimal habitats (Pulliainen 1984; Sokolov et al. 2009).

Our results are based on habitat use data which were derived from pellet distribution patterns and detection probability. Its estimates during the vegetation period were very high with figures all above 0.88 for different small-scale habitat types. They minimize a potential bias emerging from low, habitat-specific detection probabilities. However, we cannot exclude that a small fraction of absence plot was used just because there were no pellets. Thus, the sampling design might not be entirely balanced. However, it also indicates the methodological trade-off between imperfect knowledge about hare distribution and density in the study area and an accurate and efficient field method to effectively estimate relative hare abundance under harsh field conditions. We assume that a probable bias of this first time applied method is negligible, mainly because the detection probabilities were high and results are in line with previous studies and field observations on hares in general, but novel for mountain hares.

\section{Management recommendations}

Our results showed that fecal pellet survey is a suitable method for studying habitat use by mountain hares on cleared and uncleared plots. Pellet counting on uncleared plots are adequate to investigate the relative importance of habitat structure and composition for mountain hares and to study the spatial distribution of hares in areas with limited knowledge. However, we recommend the use of pre-cleared plots with interannual revisiting for field studies that strive for a precise seasonal allocation of the samples and 
simultaneously minimizing the influence of pellet decomposition.

We determined crucial and limited environmental resources for mountain hares that balance foraging benefits and predation risks. A structurally and compositionally heterogeneous habitat along the upper timberline is important as patchy habitat mosaics enable the species to adjust its activity pattern to changing environmental conditions and, thus, to optimize its trade-off between food and shelter.

The ongoing abandonment of alpine farming and subsequent reforestation in the Alps (Ceschi 2006; Speich et al. 2011) can be detrimental because it causes a vegetation homogenization and loss of structural diversity by an increasing dominance of timber and mature tree stands in the long term. The abandonment of grazing and the subsequent vegetation succession is considered to have negative effects to various taxa that depend on semi-open, patchy habitats (birds, (Laiolo et al. 2004; dung beetles,(Tocco et al. 2013; and vegetation,(Stöcklin et al. 2007).

A mosaic of forest habitats intermixed with elements of dwarf shrub and pastoral vegetation has shown to be important for the mountain hare. Thus, disturbance originating from natural (e.g., avalanches, storms, grazing by wildlife) or anthropogenic (pastoralism, forestry measures) causes at the upper timber line is expected to increase habitat suitability for the mountain hare. For instance, irregular thinning activities in timber and mature stands increase the abundance of gaps and ecotone elements and simultaneously stimulate ground vegetation growth as well as natural forest regeneration and the development of basal-branched trees. Beside mountain hares, also other medium-sized wildlife species such as grouse profit from basal-branched trees as shelter elements (Bollmann et al. 2005; Braunisch et al. 2014). Grazing by livestock and wild herbivores delays woody vegetation succession (Mayer and Stöckli 2005) and, thus, increases the patchiness of habitat. It is important to keep these areas free of touristic infrastructure and leisure activities because frequent human disturbance has a negative effect on the energy budget of the mountain hare, in particular during winter, when access to food resources is limited by snow (Rehnus et al. 2014).

\footnotetext{
Acknowledgments We would like to thank the Swiss National Park for permission to conduct this study at sites C and D, Marco Salvioni for his support in organizing the fieldwork at sites $\mathrm{E}$ and F, and Erin Gleeson, Christa Mosler-Berger, three anonymous reviewers, and the associated Editor Paulo C. Alves for constructive and insightful comments on an earlier version of this manuscript. Lea Jost also thanks Werner Suter for his competent support throughout her master thesis.
}

\section{Appendix}

Table 4 Densities of pellet locations $(N / \mathrm{km})$ of mountain hares yearround (I) and during summer (II) in the six study sites in the Northern, Central, and Southern Alps of Switzerland

\begin{tabular}{|c|c|c|c|c|c|c|c|}
\hline & & \multicolumn{2}{|c|}{ North } & \multicolumn{2}{|c|}{ Central } & \multicolumn{2}{|c|}{ South } \\
\hline & & A & $\mathrm{B}$ & $\mathrm{C}$ & $\mathrm{D}$ & $\mathrm{E}$ & $\mathrm{F}$ \\
\hline \multirow[t]{11}{*}{ (I) } & Year-round $(N / \mathrm{km})$ & 1.3 & 2.7 & 7.8 & 12.5 & 4.5 & 3.5 \\
\hline & at 1600 a.s.1. $(\mathrm{N} / \mathrm{km})$ & 7.5 & 4.3 & - & - & 5.0 & 1.0 \\
\hline & at 1700 a.s.l. $(N / \mathrm{km})$ & 2.0 & 3.4 & 0.0 & 5.9 & 6.1 & 4.2 \\
\hline & at 1800 a.s.l. $(N / \mathrm{km})$ & 1.0 & 0.0 & 2.9 & 4.3 & 1.1 & 2.3 \\
\hline & at 1900 a.s.l. $(N / \mathrm{km})$ & 0.0 & 2.9 & 3.2 & 7.8 & 2.0 & 4.1 \\
\hline & at 2000 a.s.l. $(N / \mathrm{km})$ & 0.0 & 2.0 & 9.1 & 12.3 & 4.3 & 5.9 \\
\hline & at 2100 a.s.l. $(N / \mathrm{km})$ & 0.0 & 4.1 & 14.3 & 22.1 & 7.2 & 2.4 \\
\hline & at 2200 a.s.1. $(N / \mathrm{km})$ & 0.0 & 1.7 & 12.5 & 19.1 & 3.8 & 0.0 \\
\hline & at 2300 a.s.1. $(N / \mathrm{km})$ & - & 18.3 & 23.5 & 13.2 & 14.5 & - \\
\hline & at 2400 a.s.l. $(N / \mathrm{km})$ & - & 0.0 & 4.9 & 16.0 & 5.1 & - \\
\hline & at 2500 a.s.1. $(N / \mathrm{km})$ & - & 0.0 & 8.2 & - & - & - \\
\hline \multirow[t]{11}{*}{ (II) } & Summer $(N / \mathrm{km})$ & 0.5 & 2.9 & 4.5 & 5.7 & 2.0 & 1.5 \\
\hline & at 1600 a.s.l. $(N / \mathrm{km})$ & 3.2 & 3.6 & - & - & 0.8 & 0.0 \\
\hline & at 1700 a.s.1. $(N / \mathrm{km})$ & 0.3 & 1.9 & 0.0 & 0.0 & 5.2 & 2.1 \\
\hline & at 1800 a.s.l. $(N / \mathrm{km})$ & 0.0 & 5.7 & 0.0 & 0.0 & 1.1 & 0.6 \\
\hline & at 1900 a.s.l. $(N / \mathrm{km})$ & 0.0 & 0.0 & 1.2 & 1.0 & 1.0 & 2.1 \\
\hline & at 2000 a.s.l. $(N / \mathrm{km})$ & 0.0 & 1.6 & 2.2 & 15.9 & 1.1 & 3.0 \\
\hline & at 2100 a.s.l. $(N / \mathrm{km})$ & 1.0 & 2.0 & 9.3 & 6.1 & 0.0 & 0.0 \\
\hline & at 2200 a.s.l. $(N / \mathrm{km})$ & 0.0 & 2.6 & 10.0 & 9.5 & 1.0 & 0.0 \\
\hline & at 2300 a.s.l. $(N / \mathrm{km})$ & - & 0.0 & 17.6 & 10.1 & 0.0 & - \\
\hline & at 2400 a.s.l. $(N / \mathrm{km})$ & - & 2.9 & 4.4 & 6.4 & 2.5 & - \\
\hline & at 2500 a.s.l. $(\mathrm{N} / \mathrm{km})$ & - & 10.1 & 4.5 & - & - & - \\
\hline
\end{tabular}

\section{References}

Adams L (1959) An analysis of a population of snowshoe hares in northwestern Montana. Ecol Monogr 29:141-170

Angerbjörn A (1983) Reliability of pellet counts as density estimates of mountain hares. Finn Game Res 41:13-20

Barton K (2014) Package "MuMin". Version 1.13.4. Available on: http:// mumin.r-forge.r-project.org/MuMIn-manual.pdf. Accessed 19 Jun 2014

Bisi F, Nodari M, Dos Santos Oliviera NM, Masseroni E, Preatoni DG, Wauters LA, Martinoli A (2013) Habitat selection and activity patterns in Alpine mountain hare (Lepus timidus varronis). Mamm Biol 78:28-33

Bollmann K, Weibel P, Graf RF (2005) An analysis of central Alpine capercaillie spring habitat at the forest stand scale. For Ecol Manag 215:307-318

Boyce MS, McDonald LL (1999) Relating populations to habitats using resource selection functions. Trends Ecol Evol 14:268-272

Braunisch V, Coppes J, Arlettaz R, Suchant R, Zellweger F, Bollmann K (2014) Temperate mountain forest biodiversity under climate 
change: compensating negative effects by increasing structural complexity. Plos One 9, e97718

Burnham KP, Anderson DR (2002) Model selection and multi-model inference: a practical information-theoretic approach. Springer, New York

Ceschi I (2006) Il Bosco del cantone Ticino. Edizioni Cant. del Dip. Territorio. Armando Dadó Editore, Locarno

Development Core Team R (2013) R: a language and environment for statistical computing. R Foundation for Statistical Computing, Vienna

Eaton BR (1993) Estimates of snowshoe hare abundance from pellet plot counts: a critical evaluation. Thesis, Acadia University, Wolfville, Nova Scotia, Canada

Erwacha MVA, Roth JD, Brook RK (2014) Vegetation structure and composition determine snowshoe hare (Lepus americanus) activity at arctic tree line. Can J Zool 92:789-794

Focardi S, Rizzotto M (1999) Optimal strategies and complexity: a theoretical analysis of the anti-predatory behavior of the hare. Bull Math Biol 61:829-847

Gonseth Y, Wohlgemuth T, Sansonnens B, Buttler A (2001) Die biogeographischen Regionen der Schweiz. Erläuterungen und Einteilungsstandard. Umwelt Materialien, vol 137. Federal Office for the Environment, Bern

Gorini L, Linnell JDC, May R, Panzacchi M, Boitani L, Odden M, Nilsen EB (2012) Habitat heterogeneity and mammalian predator-prey interactions. Mammal Rev 42:55-77

Grace J, Easterbee N (1979) Natural shelter for red deer (Cervus elaphus) in a Scottish glen. J Appl Ecol 16:37-48

Haller H, Eisenhut A, Haller R (2013) Atlas des Schweizerischen Nationalparks. Die ersten 100 Jahre. Nationalparkforschung Schweiz, vol 1. Haupt, Bern

Hewson R (1990) Behaviour, population changes and dispersal of mountain hares (Lepus timidus) in Scotland. J Zool (Lond) 220:287-309

Hewson R, Hinge MDC (1990) Characteristics of the home range of mountain hares Lepus timidus. J Appl Ecol 27:651-666

Hik DS (1995) Does risk of predation influence population dynamics? Evidence from cyclic decline of snowshoe hares. Wildl Res 22:115129

Hiltunen M, Kauhala K (2006) Selection of sapling stand habitats by the mountain hare (Lepus timidus) during winter. Mamm Biol 71:183189

Hiltunen M, Kauhala K, Linden H (2004) Habitat use of the mountain hare Lepus timidus in summer: the importance of different vegetation layers. Acta Theriol 49:479-490

Hirakawa H (2001) Coprophagy in leporids and other mammalian herbivores. Mammal Rev 31:61-80

Hodges KE, Mills LS, Murphy KM (2009) Determinants of snowshoe hare distribution and abundance in Yellowstone National Park. J Mammal 90:870-878

Hulbert IAR, Iason GR, Racey PA (1996) Habitat utilization in a stratified upland landscape by two lagomorphs with different feeding strategies. J Appl Ecol 33:315-324

Hulbert IAR, Iason GR, Mayes RW (2001) The flexibility of an intermediate feeder: dietary selection by mountain hares measured using faecal n-alkanes. Oecologia 129:197-205

Iason GR, Van Wieren SE (1999) Digestive and ingestive adaptations of mammalian herbivores to low-quality forage. In: Olff $\mathrm{H}$, Brown VK, Drent RH (eds) Herbivores: between plants and predators. Blackwell Scientific, Oxford, pp 337-369

IUCN (2014) Protected Areas Category Ia. IUCN. https://www.iucn.org/ about/work/programmes/gpap_home/gpap_quality/gpap_ pacategories/gpap cat1a/. Accessed 19 Jun 2014

Johnson JB, Omland KS (2004) Model selection in ecology and evolution. Trends Ecol Evol 19:101-108

Keith LB, Windberg LA (1978) Demographic analysis of snowshoe hare cycle. Wildl Monogr:6-70
Keller M (ed) (2005) Schweizerisches Landesforstinventar: Anleitung für die Erhebung 2004-2007. Swiss Federal Institute of Forest, Snow and Landscape Research WSL Birmensdorf

Kielland K, Olson K, Euskirchen E (2010) Demography of snowshoe hares in relation to regional climate variability during a 10 -year population cycle in interior Alaska. Can J For Res 40:1265-1272

Krebs CJ, Gilbert BS, Boutin S, Boonstra R (1987) Estimation of snowshoe hare population density from turd transects. Can J Zool 65 : $565-567$

Krebs CJ, Boonstra R, Nams V, O'Donoghue M, Hodges KE, Boutin S (2001) Estimating snowshoe hare population density from pellet plots: a further evaluation. Can J Zool 79:1-4

Laiolo P, Dondero F, Ciliento E, Rolando A (2004) Consequences of pastoral abandonment for the structure and diversity of the alpine avifauna. J Appl Ecol 41:294-304

Lewis CW, Hodges KE, Koehler GM, Mills LS (2011) Influence of stand and landscape features on snowshoe hare abundance in fragmented forests. J Mammal 92:561-567

Lima SL, Dill LM (1990) Behavioral decisions made under the risk of predation: a review and prospectus. Can J Zool 68:619-640

Litvaitis JA, Sherburne JA, Bissonette JA (1985) A comparison of methods used to examine snowshoe hare habitat use. J Wildl Manag 49:693-695

Loidl B (1997) Nahrungsökologie des Alpenschneehasen (Lepus timidus varronis Miller 1901) und Entwicklung einer molekularbiologischen Methode der Nahrungsanalyse von Herbivoren. Dissertation, Paris London University Salzburg

Marchand PJ (1991) Life in the cold. An introduction to winter ecology, 2nd edn. University Press of New England, Hannover and London

Mayer AC, Stöckli V (2005) Long-term impact of cattle grazing on subalpine forest development and efficiency of snow avalanche protection. Arct Antarct Alp Res 37:521-526

Mills MGL, Broomhall LS, Du Toit JT (2004) Cheetah Acinonyx jubatus feeding ecology in the Kruger National Park and a comparison across African savanna habitats: is the cheetah only a successful hunter on open grassland plains? Wildl Biol 10:177-186

Mills LS, Griffin PC, Hodges KE, McKelvey K, Ruggiero L, Ulizio T (2005) Pellet count indices compared to mark-recapture estimates for evaluating snowshoe hare density. J Wildl Manag 69:1053-1062

Murray DL, Roth JD, Ellsworth E, Wirsing AJ, Steury TD (2002) Estimating low-density snowshoe hare populations using fecal pellet counts. Can J Zool 80:771-781

Murray D, Ellsworth E, Zack A (2005) Assessment of potential bias with snowshoe hare fecal pellet-plot counts. J Wildl Manag 69:385-395

Neff DJ (1968) The pellet-group count technique for big game trend, census, and distribution: a review. J Wildl Manag 32:597-614

Newbury TL, Simon NPP (2005) The effects of clear-cutting on snowshoe hare (Lepus americanus) relative abundance in central Labrador. For Ecol Manag 210:131-142

Nielsen SE, Stenhouse GB, Boyce MS (2006) A habitat-based framework for grizzly bear conservation in Alberta. Biol Conserv 130: 217-229

Nieminen P, Mustonen AM (2008) A preliminary study on the seasonal body temperature rhythms of the captive mountain hare (Lepus timidus). Cryobiology 56:163-167

Nodari M (2006) Ecological role of mountain hare (Lepus timidus) in the alpine ecosystem. Habitat use, population consistency and dynamics of a species of conservation and management interest. University Insubria

O'Donoghue M (1983) Seasonal habitat selection by snowshoe hare in eastern. Maine Trans Northeast Fish Wildl Conf 40:100-107

Oksanen T, Oksanen L, Schneider M, Aunaupuu M (2001) Regulation, cycles and stability in northern carnivore-herbivore systems: back to first principles. Oikos 94:101-117

Olsson O, Brown JS, Helf KL (2008) A guide to central place effects in foraging. Theor Popul Biol 74:22-33 
Ott E, Frehner M, Frey HU, Lüscher P (1997) Gebirgsnadelwälder: praxisorientierter Leitfaden für eine standortgerechte Waldbehandlung. Haupt Publisher, Bern Stuttgart Wien

Pehrson A, Lindlöf B (1984) Impact of winter nutrition on reproduction in captive mountain hares (Lepus timidus). (Mammalia: Lagomorpha). J Zool (Lond) 204:201-209

Perry ME, Robertson AW (2012) Cleared and uncleared plots as indices of brown hare density. N Z J Ecol 36:157-163

Prugh LR, Krebs CJ (2004) Snowshoe hare pellet-decay rates and aging in different habitats. Wild Soc Bull 32:386-393

Pulliainen E (1984) The refuge theory and habitat selection in the mountain hare on a subarctic fell in Finnish. For Lapland Finn Game Res 41:39-44

Pyörnila A, Putaala A, Hissa R, Sulkava S (1992) Adaptations to environment in the mountain hare (Lepus timidus) - thermal physiology and histochemical properties of locomotory muscles. Can J Zool 70: $1325-1330$

Rehnus M (2013) Der Schneehase in den Alpen: Ein Überlebenskünstler mit ungewisser Zukunft. Bristol-Stiftung, Zurich. Haupt, Bern

Rehnus M (2014) The 24-hour cycle of the mountain hare Lepus timidus. Zool Gart 83:140-145

Rehnus M, Palme R, Filli F, Hackländer K (2010) Seasonal glucocorticoid secretion in mountain hares (Lepus timidus). Mammalia 74: $347-350$

Rehnus M, Marconi L, Hackländer K, Filli F (2013) Seasonal changes in habitat use and feeding strategy of the mountain hare (Lepus timidus) in the Central Alps. Hystrix 24:161-165

Rehnus M, Wehrle M, Palme R (2014) Mountain hares Lepus timidus and tourism: stress events and reactions. J Appl Ecol 51:6-12

Schütz M, Risch AC, Leuzinger E, Krüsi BO, Achermann G (2003) Impact of herbivory by red deer (Cervus elaphus L.) on patterns and processes in subalpine grasslands in the Swiss National Park. For Ecol Manag 181:177-188
Shannon CE, Weaver W (1963) The mathematical theory of communication. University of Illinois Press, Champaign

Sih A (1980) Optimal behavior: can foragers balance two conflicting events? Sci (Washington D C) 210:1041-1043

Slotta-Bachmayr L (1998) Biologie und Ökologie des Alpenschneehasen (Lepus timidus varronis Miller 1901). Verbreitung, Raumnutzung, Aktivität und Habitatwahl in den Hohen Tauern. Paris London University Salzburg

Sokolov VE, Ivanitskaya EY, Gruzdev VV, Heptner VG (2009) Lagomorphs. Mammals of Russia and adjacent regions. Smithsonian Institution Libraries, Washington

Speich S et al (2011) Drittes Schweizerisches LandesforstinventarErgebnistabellen im Internet. Zweite stark erweiterte Ausgabe. [Published online 31.03.2011] Available from World Wide Web $<$ http://www.lfi.ch/resultate/>. Swiss Federal Institute of Forest, Snow and Landscape Research WSL. http://www.lfi.ch/resultate. Accessed 19 Jun 2014

Stöcklin J, Bosshard A, Klaus G, Rudmann-Maurer K, Fischer M (2007) Landnutzung und biologische Vielfalt in den Alpen. vdf Hochschulverlag AG, Zurich

Thulin C-G (2003) The distribution of mountain hares Lepus timidus in Europe: a challenge from brown hares L. europaeus? Mammal Rev 33:29-42

Thulin C-G, Flux JEC (2003) Lepus timidus Linnaeus, 1758Schneehase. In: Krapp F (ed) Handbuch der Säugetiere Europas Band, 3/II: Hasenartige Lagomorpha. Aula Publisher, Wiebelsheim, pp 155-185

Tocco C, Negro M, Rolando A, Palestrini C (2013) Does natural reforestation represent a potential threat to dung beetle diversity in the Alps? J Insect Conserv 17:207-217

Wolff JO (1980) The role of habitat patchiness in the population dynamic of snowshoe hares. Ecol Monogr 50:111-130 